\title{
ВПРОВАДЖЕННЯ ІННОВАЦІЙНИХ МЕТОДІВ У НАВЧАЛЬНИЙ ПРОЦЕС ФАРМАЦЕВТИЧНОГО ВУЗУ
}

\author{
M. M. Suleiman
}

\section{The National University of Pharmacy, Kharkiv \\ INNOVATIVE METHODS IMPLEMENTATION INTO EDUCATIONAL PROCESS OF THE PHARMACEUTICAL UNIVERSITY}

\begin{abstract}
Мета роботи - дослідження ефективності впровадження інноваційних методів навчання в підготовці кваліфікованих спеціалістів фармації.

Для проведення дослідження були використані новітні інформаційно-комунікаційні технології, а саме: інтернет-сайти, блог-технології, аудіо- і відеоресурси, програма Skype, мультимедійні презентації, проведення тренінгів, рольових ігор та тестування на комп’ютерах.

Основна частина. Використання інноваційних освітніх технологій у Національному фармацевтичному університеті надає великі можливості для підвищення ефективності процесу навчання. Інформаційні і мультимедійні навчальні програми сприяють не лише якісному засвоєнню теоретичного матеріалу, але й удосконаленню навичок володіння комп’ютерною технікою. Інновації у змісті освіти мають доповнюватися і реалізовуватися через оволодіння інноваційними методами. Одним із таких методів, який доцільно застосовувати в підготовці майбутніх фармацевтів, є кейс-метод. Використання цього методу у формі кейс-випадку, кейс-вправи та кейс-ситуації на заняттях із клінічної фармації, фармакогнозії, фармацевтичної хімії, аптечної та заводської технології ліків в осінньому семестрі 2016 р. привело до підвищення показників якісної успішності студентів середньостатистичної групи на 20-25\%.

Висновки. Використання інноваційних методів навчання в освітньому процесі несе в собі великий потенціал, бо прискорює оволодіння знаннями і робить цей процес цікавим і динамічним. Застосування інтерактивного методу (кейс-методу) щодо профільних дисциплін показало підвищення якісної успішності студентів порівняно з використанням традиційних методів.
\end{abstract}

Ключові слова: інноваційні технології; інноваційні методи; кейс-метод.

The aim of the study - to investigate the effectiveness of innovative teaching methods implementing to train qualified pharmacy professionals.

For conducting the study the modern information and communication technologies were used, namely: Internet sites, blog technology, audio and video resources, Skype program, multimedia presentations, trainings, role plays and computer-based testing.

The main body. The use of innovative educational technologies in the National University of Pharmacy provides great opportunities to improve the learning process effectiveness. Information and multimedia educational programs facilitate not only high-quality digestion of theoretical material, but also computers skills improving. Innovations in the content of education should be supplemented and implemented through the mastery of innovative methods. One of the methods, which is appropriate to be used within future pharmacists training is case-method. Using this method in the form of a case-by-case, case exercise and case situation during Clinical Pharmacology, Pharmacognosy, Pharmaceutical Chemistry and Pharmaceutical and Industrial Drugs Technology classes during autumn semester of 2016 led to the increase of indicators of qualitative students' achievement of average statistical group by 20-25 \%.

Conclusion. The use of innovative teaching methods in the educational process carries a great potential, because it accelerates the mastery of knowledge and makes this process interesting and dynamic. The use of interactive method (case method) as to core subjects showed improving of qualitative students' achievement compared to using traditional methods.

Key words: innovative technologies; innovative methods; case method.

Вступ. ХХІ століття - ера інноваційних технологій, які активно впроваджуються в усі сфери життя. Оскільки освіта є фундаментом розвитку суспільства, доповнення традиційної системи викладання передовими технологіями є одним із пріоритетних

\footnotetext{
(c) М. М. Сулейман
}

напрямків державної політики України [1]. Разом 3 тим інтеграція вітчизняної освітньої галузі до європейського та світового освітнього простору прискорює цей процес.

Інноваційна освіта спонукає студентів до оволодіння новими знаннями, мобілізує їх задатки, 
здібності та обдарованість, утверджуються навики брати на себе відповідальність, відстоювати свою позицію, співпрацювати, розвивається новий тип мотиваційної сфери, де самоактуалізація впливає на загальну креативність студента, сприяє створенню нової позиції особистості [2].

Мета роботи - дослідження ефективності впровадження інноваційних методів навчання в підготовці кваліфікованих спеціалістів фармації.

Для проведення дослідження були використані новітні інформаційно-комунікаційні технології, а саме: інтернет-сайти, блог-технології, аудіо- і відеоресурси, програма Skype, мультимедійні презентації, проведення тренінгів, рольових ігор та тестування на комп’ютерах.

Основна частина. Сучасні методи $з$ використання інформаційно-комунікаційних технологій удосконалюють, урізноманітнюють навчальний процес, роблять його більш цікавим і пізнавальним для студентів як очної, так і дистанційної форм навчання. Узагальнюючи практику використання інформаційно-комунікаційних технологій, можна виділити такі напрямки роботи:

1) використання ряду інтернет-сайтів;

2) застосування програми Skype;

3) пошук студентами додаткової до навчального курсу інформації в Інтернеті за завданням викладача;

4) пошук додаткової до навчального курсу інформації в Інтернеті викладачем для використання її на практичних заняттях зі студентами;

5) використання блог-технологій для організації самостійної роботи студентів;

6) використання системи дистанційної освіти.

Максимальне використання інноваційних технологій під час навчання, зокрема особистісно-орієнтованих й інформаційних, сприяє орієнтації освіти від процесу до результату.

Особистісно-орієнтовані технології представлені технологіями диференціації й індивідуалізації навчання, проектними тощо. Основними формами використання інформаційних технологій є такі: мультимедіауроки, що проводяться на основі комп'ютерних навчальних програм; уроки на основі авторських комп’ютерних презентацій у ході лекцій, семінарів, лабораторних робіт, доповідей студентів; тестування на комп’ютерах; телекомунікаційні проекти, робота з аудіо- і відеоресурсами в режимі он-лайн; дистанційне навчання, що включає усі форми освітньої активності, здійснювані без особистого контакту викладача й студента.
Інновації у змісті освіти мають доповнюватися і реалізовуватися через оволодіння інноваційними методами і формами навчання (діалоговими, діагностичними, активними, інтерактивними, дистанційними, комп’ютерними, мультимедійними, телекомунікаційними, тренінговими, проектними), а також шляхом запровадження альтернативних навчально-виховних технологій, таких, як алгоритмізована, індивідуалізована, диференційована, модульна, колективна (у малих групах) тощо [3].

За допомогою інноваційних методів студенти вчаться аналізувати складні ситуації, знаходити причини їх виникнення і способи та засоби вирішення. У майбутніх фахівців розвивається вміння аргументувати свою точку зору, чітко формулювати та ясно викладати думки, розвивається пізнавальна та емоційно-вольова сфери особистості. Студенти активним способом отримують нові знання, розвивають творчі здібності, стають соціально активними людьми. Нові методи викладання максимально наближують освітній процес до практики повсякденного життя.

Одним із методів, який доцільно застосовувати в підготовці майбутніх фармацевтів, $є$ кейс-метод. Застосування кейс-методу базується на індивідуальному підході до кожного студента, максимальній свободі в навчанні, самостійності мислення, самоорганізованості, умінні працювати з інформацією. Забезпечення студентів достатньою кількістю наочних матеріалів спонукає їх мислення до концентрації на основних положеннях, а не на великому об’ємі теоретичного матеріалу, акцентує увагу на розвиток позитивних і необхідних для подальшого удосконалення якостей майбутнього кваліфікованого фармацевта.

Метод case-study (від англ. case - випадок, ситуація), або метод конкретних ситуацій, - це педагогічна технологія, основана на моделюванні ситуації, виявленні проблеми і прийнятті рішення. Мета методу - поставити студентів у таку ситуацію, коли їм необхідно буде прийняти рішення [4]. Кейс - це події, які реально відбулися в певній сфері діяльності і є основою для проведення обговорення в академічній групі під керівництвом викладача. Кейс-технології основані на самостійному вивченні друкованих і мультимедійних навчальнометодичних матеріалів, що надаються студенту в спеціальній формі (кейс). Суть технології полягає у використанні конкретних ситуацій для спільного аналізу, обговорення або вироблення рішень із певного розділу дисципліни. 
Складовими кейс-методу є обговорення та дискусія. При цьому студенти спільними зусиллями аналізують ситуацію - case, що дозволяє їм виробити практичне рішення, завершенням якого є оцінка запропонованих алгоритмів, вибір найкращого $з$ них у контексті поставленого завдання чи проблеми. Демонстрація кейсів можлива у друкованій формі, мультимедійній та відеоформах [5].

У фармацевтичних вузах кейс-метод використовують на заняттях із клінічної фармації, фармакогнозії, фармацевтичної хімії, аптечної та заводської технології ліків.

За типом задач кейси поділяють на кейс-випадок, кейс-вправу та кейс-ситуацію. Кейс-випадок використовують під час лекцій з аптечної та заводської технології, для того, щоб проілюструвати певну технологію лікарської форми, обгрунтувати етапи виробництва та підбір сировинної бази. На семінарах з фармацевтичної хімії та фармакогнозії кейс-випадок допомагає студентам орієнтуватися в правильності вибору якісного та кількісного аналізу субстанцій і лікарської рослинної сировини. Кейс-вправа надає студенту можливість застосувати на практиці здобуті навички та найчастіше використовується там, де необхідно провести фармацевтичну опіку. У кейсі-ситуації використовують нетипові задачі, наприклад, у процесі виготовлення лікарських засобів на виробництві можливе порушення технологічного процесу, що призводить до отримання бракованої продукції, через що проходить навчання алгоритму прийняття рішення в певній ситуації. Кейс-ситуація потребує часу для ознайомлення, тому вимагає від студентів самостійної підготовки.

Впровадження кейс-методу в навчальний процес Національного фармацевтичного університету осіннього семестру 2016 р. привело до підвищення показників якісної успішності студентів середньостатистичної групи на 20-25 \%.

Таким чином, кейс-метод дає змогу доповнити арсенал методичних прийомів, бо легко поєднується з іншими методами навчання. Він сприяє розвитку практичних навичок майбутніх спеціалістів, спонукає студентів до творчої роботи, ефективний у засвоєнні навчального матеріалу, дозволяє у штучній атмосфері виробляти певні алгоритми вирішення критичних ситуацій, які будуть виникати в практичній діяльності майбутніх фармацевтів.

Висновки. 1. Використання інноваційних методів навчання в освітньому процесі несе в собі великий потенціал, бо прискорює оволодіння знаннями і робить цей процес цікавим і динамічним.

2. Студент, отримуючи максимум передової наукової інформації, вчиться працювати 3 нею, стає більш самоорганізованим, розвиває здібності до самостійного мислення i, як результат, вчиться вирішувати як традиційні завдання, так і нові, які потребують творчих підходів, сучасних методів і методології розв'язання.

3. Використання кейс-методу в підготовці кваліфікованих спеціалістів у галузі фармації сприяє опануванню практичних навичок, вихованню творчого підходу до аналізу даних, навчає студента аналізу та синтезу при роботі з інформацією, колегіального підходу вирішення задач, сприяє професійному розвитку викладачів і студентів.

Подальші дослідження в цьому напрямку будуть мати позитивний характер, оскільки інноваційні нововведення в освіту сприяють кращому засвоєнню студентами теоретичного матеріалу, розвивають творчі здібності, стимулюють до саморозвитку і самоосвіти.

\section{Список літератури}

1. Матеріали виїзного спільного засідання Комітету Верховної Ради України з питань науки і освіти та Консультативної ради з питань інформатизації при Верховній Раді України про хід виконання Державної програми “Інформаційні та комунікаційні технології” / Ком. Верх. Ради України з питань науки і освіти ; упоряд.: І. Б. Жиляєв, М. К. Родіонов, А. І. Семенченко, редкол.: К. С. Самойлик (голова) та ін. - К. : СофтПрес, 2007. - С. 53-54.

2. Козак Л. В. Дослідження інноваційних моделей навчання у вищій школі / Л. В. Козак [Електронний ресурс].Режим доступу : http://elibrary.kubg.edu.ua.

3. Силадій I. Якісна освіта в контексті управління впровадженням інновацій / I. Силадій // Вища освіта України. - 2011. - № 4. - С. 105-112.

4. Педагогіка вищої школи. Метод кейсів (вирішення практичних проблем) [Електронний ресурс]. - Режим доступу : http://pidruchniki.com/18380828/pedagogika/ mikrovikladannya.

5. Скринник 3. Е. Психологія і педагогіка. Проведення індивідуального заняття за методом аналізу конкретних навчальних ситуацій (case study) : навч.-метод. посіб. / 3. Е. Скринник. - Львів : ЛІБС УБС НБУ, 2012. - 145 с. 


\section{References}

1. Zhyliaiev, I.B., Rodionov, M.K., Semenchenko, A.I., \& Samoilyk, K.S. (Eds.) (2007). Materialy vyizdnoho spilnoho zasidannia Komitetu Rady Ukrainy z pytan nauky i osvity ta Konsultatyvnoi rady z pytan informatyzatsii pry Verhovnii Radi Ukrainy pro khid vykonannia Derzhavnoi programy «Informatsiini ta komunikatsiini tekhnolohii» [Materials of on-site meeting of the Commitee of Verkhovna Rada of Ukraine on Science and Education Issues and the Advisory Council on Informatization issues under the Verkhovna Rada of Ukraine on the implementation of the State Program "Information and Communication Technologies"]. Kyiv: SoftPres [in Ukrainian].

2. Kozak, L.V. (2014). Doslidzhennia innovvatsiinykh modelei navchania u vyshchii shkoli [Innovative models of teaching in higher educational institution study]. Retrieved from http://elibrary.kubg.edu.ua [in Ukrainian].
3. Syladii, I. (2011) Yakisna osvita v konteksti upravlinnia vprovadzhenniam innovatsii [High-quality education in the context of innovation implementation management]. Vyshcha osvita Ukrainy - Higher education of Ukraine, 4, 105-112 [in Ukrainian].

4. Pedahohika vyshchoi shkoly. Metod keisiv (vyrishennia praktychnykh problem [Pedagogy of high school. Method cases (solving practical problems)]. Retrieved from http:/pidruchniki.com/18380828/pedagogika/ mikrovikladannya.

5. Skrynnyk, Z.E. (2012) Psykholohiia i pedahohika. Provedennia indyvidualnoho zaniattia za metodom analizu konkretnykh navchalnykh sytuatsii (case study) [Psychology and Pedagogy. Conducting individual lessons by the method of analysis of specific learning situations]. Lviv: LIBS UBS NBU [in Ukrainian].

Електронна адреса для листування: suleiman.nfau@outlook.com 